\title{
Loktanella koreensis sp. nov., isolated from sea sand in Korea
}

Correspondence

Soon-Wo Kwon

swkwon@rda.go.kr

\author{
Hang-Yeon Weon, ${ }^{1}$ Byung-Yong Kim, ${ }^{2}$ Seung-Hee Yoo, ${ }^{2}$ Jong-Shik Kim, ${ }^{3}$ \\ Soon-Wo Kwon, ${ }^{2}$ Seung-Joo Go ${ }^{2}$ and Erko Stackebrandt ${ }^{4}$ \\ ${ }^{1,2}$ Applied Microbiology Division, National Institute of Agricultural Science and Technology ${ }^{1}$, \\ and Korean Agricultural Culture Collection (KACC), Genetic Resources Division, National \\ Institute of Agricultural Biotechnology2, Rural Development Administration (RDA), \\ Suwon 441-707, Republic of Korea \\ ${ }^{3}$ Department of Environmental Sciences, University of California, Riverside, CA 92521-0424, \\ USA \\ ${ }^{4}$ DSMZ - Deutsche Sammlung von Mikroorganismen und Zellkulturen GmbH, Mascheroder \\ Weg 1b, D-38124 Braunschweig, Germany
}

\begin{abstract}
A bacterial strain, GA2-M3 ${ }^{\top}$, isolated from a sea-sand sample in Korea, was subjected to polyphasic taxonomic characterization. Cells of strain GA2-M3 ${ }^{\top}$ were Gram-negative, non-motile, non-spore-forming and short rod- to ovoid-shaped. Comparative 16S rRNA gene sequencing studies confirmed that the bacterium fell within the radiation of the genus Loktanella. Similarity levels between the 16S rRNA gene sequence of strain GA2-M3 ${ }^{\top}$ and those of type strains of Loktanella species with validly published names were 93.5-96.1\%; highest sequence similarity was with Loktanella rosea. The $\mathrm{G}+\mathrm{C}$ content of the genomic DNA of strain GA2-M3 ${ }^{\top}$ was $60 \cdot 0 \mathrm{~mol} \%$ and the predominant ubiquinone was Q-10. Major fatty acids were $18: 1 \omega 7 c, 18: 0$ and $18: 1 \omega 7 c$ 11-methyl. On the basis of the evidence presented, it is proposed that strain GA2-M3 ${ }^{\top}$ represents a novel species, for which the name Loktanella koreensis sp. nov. is proposed. The type strain is $\mathrm{GA} 2-\mathrm{M3}^{\top}\left(=\operatorname{KACC} 11519^{\top}=\mathrm{DSM} 17925^{\top}\right)$.
\end{abstract}

The genus Loktanella was proposed for novel bacteria isolated from Antarctic lakes (Van Trappen et al., 2004). This genus is a member of the Alphaproteobacteria and currently comprises six species, Loktanella salsilacus (the type species), L. fryxellensis, L. vestfoldensis, L. hongkongensis, L. agnita and L. rosea (Van Trappen et al., 2004; Lau et al., 2004; Ivanova et al., 2005).

In the course of a study on bacterial diversity in sea sands, a bacterial strain, GA2-M3 ${ }^{\mathrm{T}}$, was isolated in the Homi cape of Pohang City, Republic of Korea. The sea-sand samples were serially diluted with $0 \cdot 85 \% \mathrm{NaCl}(\mathrm{w} / \mathrm{v})$ and suitable 10 -fold dilutions were plated onto marine agar 2216 (MA; Difco). The plates were incubated at $25^{\circ} \mathrm{C}$ for 4 days and strain $\mathrm{GA} 2-\mathrm{M} 3^{\mathrm{T}}$ was isolated.

Cell morphology and cell dimensions were examined using phase-contrast microscopy with a Zeiss Axio Imager. To investigate physiological characteristics, strain GA2-M3 ${ }^{\mathrm{T}}$ was routinely cultivated on $\mathrm{MA}$ at $25^{\circ} \mathrm{C}$. Standard physiological tests were carried out according to the methods described by Gerhardt et al. (1994). Some

The GenBank/EMBL/DDBJ accession number for the 16S rRNA gene sequence of strain GA2-M3 ${ }^{\top}$ is DO344498. physiological properties, carbohydrate assimilation and acid production from carbon sources were tested using the API 20NE and API 50CH kits (bioMérieux). API 20NE and API 50CH kits (bioMérieux) were used according to the manufacturer's instructions except that, for the test strips, suspension solutions and media containing various salt concentrations $[0 \cdot 85,5$ and $8 \% \mathrm{NaCl}(\mathrm{w} / \mathrm{v})$ and sea salts $(0.5 \times$ and $1.0 \times$ sea salts $($ Sigma $)]$ were used as inocula. Enzyme activities were also studied using the API ZYM galleries (bioMérieux). Additionally, Biolog GP2 Microplates were used to observe oxidation of carbon sources, using inocula suspended in various concentrations of $\mathrm{NaCl}$ and sea salts. Anaerobic growth was checked using BBL anaerobic jars (Becton Dickinson), incubating for up to 21 days.

Strain GA2-M3 ${ }^{\mathrm{T}}$ did not grow on nutrient agar (NA; Difco), trypticase soy agar (TSA; Difco) or MacConkey agar (Difco). The strain did not assimilate any carbohydrates in API 20NE tests or produce any acids from substrates in API $50 \mathrm{CH}$ tests. Tests that are useful for distinguishing strain GA2-M3 ${ }^{\mathrm{T}}$ from members of the genus Loktanella are shown in Table 1. Strain GA2-M3 ${ }^{\mathrm{T}}$ could be distinguished from other Loktanella species on the basis of several biochemical characteristics and could be differentiated 
Table 1. Characteristics that differentiate strain GA2-M3 ${ }^{\top}$ from other species of the genus Loktanella

Taxa: 1, GA2-M3 ${ }^{\mathrm{T}}$; 2, L. salsilacus; 3, L. fryxellensis; 4, L. vestfoldensis; 5, L. hongkongensis; 6, L. agnita; 7, L. rosea. Data from Van Trappen et al. (2004), Lau et al. (2004), Ivanova et al. (2005) and this study. All species are catalase-positive. W, Weak reaction; V, variable reaction depending on strain; ND, no data available.

\begin{tabular}{|c|c|c|c|c|c|c|c|}
\hline Characteristic & 1 & 2 & 3 & 4 & 5 & 6 & 7 \\
\hline Diffusible pigment & - & - & - & - & Brown & - & - \\
\hline TSA & - & - & - & $\mathrm{W}$ & - & - & - \\
\hline NA & - & - & - & $\mathrm{W}$ & - & - & - \\
\hline Temperature range for growth $\left({ }^{\circ} \mathrm{C}\right)$ & $5-30$ & $5-30$ & $5-25$ & $5-37$ & $8-44$ & $8-35$ & $4-35$ \\
\hline Reduction of nitrate to nitrite & + & - & - & - & - & w & - \\
\hline \multicolumn{8}{|l|}{ Production of: } \\
\hline Lipase (Tween 80) & - & + & + & + & - & - & $\mathrm{w}$ \\
\hline Trypsin & - & - & - & + & ND & - & - \\
\hline$\alpha$-Galactosidase & - & + & - & - & $\mathrm{ND}$ & + & - \\
\hline
\end{tabular}

from L. rosea, the most closely related species, by colony pigmentation, $\mathrm{NaCl}$ range for growth and the ability to reduce nitrate.

Quinones were extracted from cells grown in marine broth and analysed as described by Groth et al. (1996) using reversed-phase HPLC. Cellular fatty acids were analysed in cells grown on MA for 2 days. Cellular fatty acids were saponified, methylated and extracted according to the protocol of the Sherlock Microbial Identification system (MIDI version 3.0). The fatty acids analysed by GC (Hewlett Packard 6890) were identified by the Microbial Identification software package. The DNA G $+\mathrm{C}$ content of GA2-M3 ${ }^{\mathrm{T}}$ was determined using an HPLC method (Mesbah et al., 1989).

The fatty acid profile of strain GA2-M3 ${ }^{\mathrm{T}}$ was typical of Loktanella species, with a predominance of $18: 1 \omega 7 \mathrm{c}$ $(66.6 \%)$, but it also contained large amounts of $18: 0$ $(9 \cdot 3 \%)$ and $18: 1 \omega 7 c 11$-methyl $(8 \cdot 7 \%)$ (Table 2$)$. The predominant respiratory quinone was Q-10. The DNA $\mathrm{G}+\mathrm{C}$ content of strain $\mathrm{GA} 2-\mathrm{M3}^{\mathrm{T}}$ was $60 \cdot 0 \mathrm{~mol} \%$.

PCR amplification of the 16S rRNA gene and sequencing of the purified PCR product were carried out according to the methods given by Kwon et al. (2003) and the almostcomplete 16S rRNA gene sequence (1375 nt of strain GA2$\mathrm{M} 3^{\mathrm{T}}$ ) was determined. Multiple alignments were performed using the program CLUSTAL X (Thompson et al., 1997). Distances were calculated according to the Kimura- 2 model (Kimura, 1980) and clustering was determined using the neighbour-joining method (Saitou \& Nei, 1987). Bootstrap analysis was based on 1000 resamplings.

A BLAST search in the NCBI database suggested that GA2$\mathrm{M} 3^{\mathrm{T}}$ was closely related to species of the genus Loktanella.
The highest 16S rRNA gene sequence similarity values were found with L. rosea KMM $6003^{\mathrm{T}}(96 \cdot 1 \%)$ and L. agnita KMM $3788^{\mathrm{T}}$ (95.2\%). A phylogenetic tree (Fig. 1) further demonstrated placement of GA2-M3 ${ }^{\mathrm{T}}$ within the genus Loktanella, where it formed a subcluster with L. rosea KMM $6003^{\mathrm{T}}$ (80\% bootstrap value). 16S rRNA gene sequence similarities between strain GA2-M3 ${ }^{\mathrm{T}}$ and all members of the genus Loktanella were $<97 \%$, indicating that strain GA2$\mathrm{M}^{\mathrm{T}}$ represents a novel genomic species (Stackebrandt \& Goebel, 1994).

Phylogenetic analysis based on 16S rRNA gene sequence and respiratory quinone analysis clearly suggests that our isolate belongs to the genus Loktanella. Furthermore, phenotypic features and the fatty acid profile clearly differentiate strain $\mathrm{GA} 2-\mathrm{M} 3^{\mathrm{T}}$ from other Loktanella species. In conclusion, it is proposed that strain GA2-M3 ${ }^{\mathrm{T}}$ represents a novel species of the genus Loktanella, for which the name Loktanella koreensis sp. nov. is proposed.

\section{Description of Loktanella koreensis sp. nov.}

Loktanella koreensis (ko.re.en'sis. N.L. fem. adj. koreensis pertaining to Korea, from where the type strain was isolated).

Cells are Gram-negative, non-motile, non-spore-forming and short rod- to ovoid-shaped $(0 \cdot 5-0 \cdot 8 \times 0 \cdot 8-1.5 \mu \mathrm{m})$. Colonies are round, convex with a clear margin and light beige in colour after 2 days on MA plates. Able to grow between 5 and $30^{\circ} \mathrm{C}$ and at $\mathrm{pH} 6 \cdot 0-9 \cdot 0$. Tolerates up to $5 \%$ $\mathrm{NaCl}$. Positive for catalase, oxidase, nitrate reduction and hydrogen sulfide production, but negative for arginine dihydrolase, glucose fermentation, indole production and Voges-Proskauer reaction. Does not grow on nutrient agar, 
Table 2. Fatty acid compositions (\%) of strain GA2-M3 ${ }^{\top}$ and members of the genus Loktanella

Taxa: 1, GA2-M3 ${ }^{\mathrm{T}}$; 2, L. salsilacus (10 strains); 3, L. fryxellensis (12 strains); 4, L. vestfoldensis (4 strains); 5, L. hongkongensis (2 strains); 6, L. agnita (1 strain); 7, L. rosea (4 strains). Data from Van Trappen et al. (2004), Lau et al. (2004), Ivanova et al. (2005) and this study. -, $<1 \%$ of total fatty acids or not detected.

\begin{tabular}{|c|c|c|c|c|c|c|c|}
\hline Fatty acid & 1 & 2 & 3 & 4 & 5 & 6 & 7 \\
\hline $10: 03-\mathrm{OH}$ & $2 \cdot 4$ & $2 \cdot 4 \pm 0 \cdot 7$ & $3 \cdot 7 \pm 1 \cdot 1$ & $6 \cdot 1 \pm 1 \cdot 5$ & $1 \cdot 8 \pm 0 \cdot 3$ & $1 \cdot 0$ & $1 \cdot 2 \pm 0 \cdot 1$ \\
\hline $12: 13-\mathrm{OH}$ & $3 \cdot 4$ & - & - & $5 \cdot 6 \pm 1 \cdot 4$ & - & - & - \\
\hline $14: 0$ & - & - & - & - & - & $4 \cdot 6$ & - \\
\hline $14: 1$ & - & - & - & - & - & $4 \cdot 6$ & - \\
\hline $16: 1 \omega 7$ & - & - & - & - & - & $1 \cdot 9$ & $1 \cdot 3 \pm 0 \cdot 3$ \\
\hline $17: 0$ & - & - & - & - & - & $1 \cdot 7$ & - \\
\hline $18: 1 \omega 7 c$ & $66 \cdot 6$ & $87 \cdot 7 \pm 1 \cdot 9$ & $84 \cdot 9 \pm 3 \cdot 7$ & $74 \cdot 1 \pm 3 \cdot 1$ & $85 \cdot 6 \pm 3 \cdot 6$ & $79 \cdot 0$ & $70 \cdot 4 \pm 2 \cdot 0$ \\
\hline $18: 1 \omega 9$ & - & - & - & - & - & $4 \cdot 4$ & $6 \cdot 4 \pm 2 \cdot 0$ \\
\hline $18: 0$ & $9 \cdot 3$ & $1 \cdot 4 \pm 0 \cdot 8$ & $1 \cdot 6 \pm 0 \cdot 9$ & $1 \cdot 8 \pm 0 \cdot 3$ & $3 \cdot 0 \pm 1 \cdot 2$ & - & $3 \cdot 6 \pm 0 \cdot 5$ \\
\hline Summed feature 3 & - & $2 \cdot 8 \pm 0 \cdot 9$ & - & - & - & - & - \\
\hline Summed feature 7 & $1 \cdot 0$ & $1 \cdot 2 \pm 1 \cdot 0$ & $4 \cdot 7 \pm 2 \cdot 0$ & $4 \cdot 7 \pm 0 \cdot 7$ & - & - & - \\
\hline Unknown $11 \cdot 799$ & - & - & - & $2 \cdot 3 \pm 1 \cdot 2$ & - & - & - \\
\hline
\end{tabular}

* Summed features consist of one or more fatty acids that could not be separated by the Microbial Identification System. Summed feature 2: $12: 0$

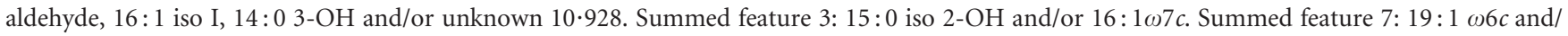
or unknown $18 \cdot 846$.

trypticase soy agar or MacConkey agar. Hydrolyses aesculin, weakly hydrolyses gelatin (prolonged incubation of more than 10 days), but does not hydrolyse agar, alginic acid, casein, chitin, carboxymethyl-cellulose, DNA, pectin, starch, Tween 80, tyrosine or urea. With API 20NE and API 50CH strips, no growth is observed on carbohydrates and acids are not produced from any substrate. Using API ZYM strips, alkaline phosphatase (weak), esterase (C4), esterase lipase (C8), leucine arylamidase, valine arylamidase (weak), cystine arylamidase (weak), $\alpha$-chymotrypsin (weak), naphthol-AS-BI-phosphohydrolase (weak), $\beta$-galactosidase (weak) and $\beta$-glucosidase (weak) are detected, but lipase (C14), trypsin, acid phosphatase, $\alpha$-galactosidase, $\beta$-glucuronidase, $\alpha$-glucosidase, $N$-acetyl- $\beta$-glucosaminidase, $\alpha$ mannosidase and $\alpha$-fucosidase are not detected. The main cellular fatty acid is 18:1 $\omega 7 c$ (approx. 67\%). Ubiquinone Q-10 is the major isoprenoid quinone.

The type strain is GA2-M3 ${ }^{\mathrm{T}}$ (= KACC $11519^{\mathrm{T}}=\mathrm{DSM}$ $\left.17925^{\mathrm{T}}\right)$, isolated from sea sand taken from Homi cape, Pohang City, Republic of Korea. The DNA G + C content of strain GA2-M3 ${ }^{\mathrm{T}}$ is $60 \cdot 0 \mathrm{~mol} \%$.

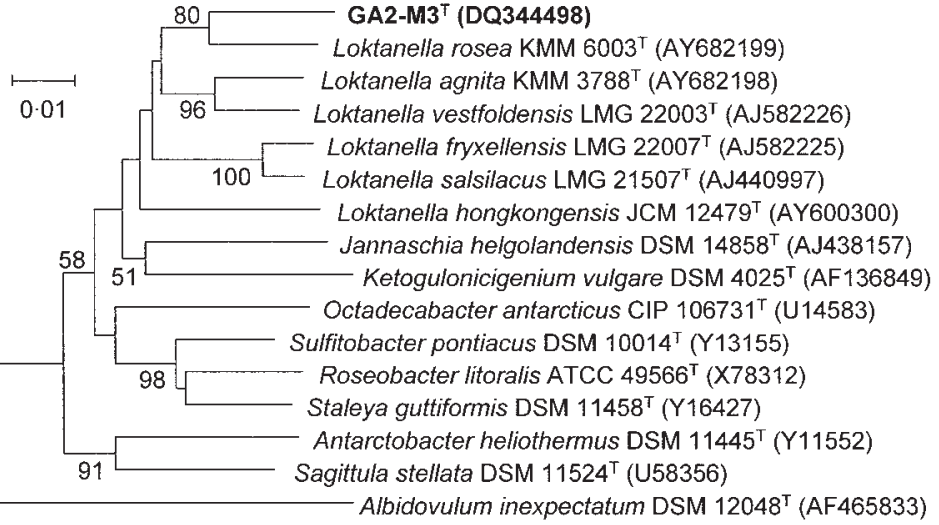

Fig. 1. Neighbour-joining dendrogram showing the phylogenetic position of $\mathrm{GA} 2-\mathrm{M3}^{\mathrm{T}}$ on the basis of $16 \mathrm{~S}$ rRNA gene sequences. The sequence length used in this tree corresponds to nt 50-1502 of the Escherichia coli 16S rRNA gene sequence (Brosius et al., 1978). Albidovulum inexpectatum DSM $12048^{\top}$ was used as an outgroup and bootstrap values (expressed as percentages of 1000 replications) greater than $50 \%$ are shown at the branch points. Bar, 0.01 substitutions per site. 


\section{Acknowledgements}

This study was supported by the Agricultural Research \& Promotion Center, Republic of Korea.

\section{References}

Brosius, J., Palmer, M. L., Kennedy, P. J. \& Noller, H. F. (1978). Complete nucleotide sequence of a $16 \mathrm{~S}$ ribosomal RNA gene from Escherichia coli. Proc Natl Acad Sci U S A 75, 4801-4805.

Gerhardt, P., Murray, R. G. E., Wood, W. A. \& Krieg, N. R. (editors) (1994). Methods for General and Molecular Bacteriology. Washington, DC: American Society for Microbiology.

Groth, I., Schumann, P., Weiss, N., Martin, K. \& Rainey, F. A. (1996). Agrococcus jenensis gen. nov., sp. nov., a new genus of actinomycetes with diaminobutyric acid in the cell wall. Int J Syst Bacteriol 46, 234-239.

Ivanova, E. P., Zhukova, N. V., Lysenko, A. M., Gorshkova, N. M., Sergeev, A. F., Mikhailov, V. V. \& Bowman, J. P. (2005). Loktanella agnita sp. nov. and Loktanella rosea sp. nov., from the north-west Pacific Ocean. Int J Syst Evol Microbiol 55, 2203-2207.

Kimura, M. (1980). A simple method for estimating evolutionary rates of base substitutions through comparative studies of nucleotide sequences. J Mol Evol 16, 111-120.

Kwon, S. W., Kim, J. S., Park, I. C., Yoon, S. H., Park, D. H., Lim, C. K. \& Go, S. J. (2003). Pseudomonas koreensis sp. nov., Pseudomonas umsongensis sp. nov. and Pseudomonas jinjuensis sp. nov., novel species from farm soils in Korea. Int J Syst Evol Microbiol 53, 21-27.

Lau, S. C. K., Tsoi, M. M. Y., Li, X., Plakhotnikova, I., Wu, M., Wong, P.-K. \& Qian, P.-Y. (2004). Loktanella hongkongensis sp. nov., a novel member of the $\alpha$-Proteobacteria originating from marine biofilms in Hong Kong waters. Int J Syst Evol Microbiol 54, 2281-2284.

Mesbah, M., Premachandran, U. \& Whitman, W. B. (1989). Precise measurement of the $\mathrm{G}+\mathrm{C}$ content of deoxyribonucleic acid by highperformance liquid chromatography. Int J Syst Bacteriol 39, 159-167.

Saitou, N. \& Nei, M. (1987). The neighbor-joining method: a new method for reconstructing phylogenetic trees. Mol Biol Evol 4, 406-425.

Stackebrandt, E. \& Goebel, B. M. (1994). Taxonomic note: a place for DNA-DNA reassociation and 16S rRNA sequence analysis in the present species definition in bacteriology. Int J Syst Bacteriol 44, 846-849.

Thompson, J. D., Gibson, T. J., Plewniak, F., Jeanmougin, F. \& Higgins, D. G. (1997). The CLUSTAL_X windows interface: flexible strategies for multiple sequence alignment aided by quality analysis tools. Nucleic Acids Res 25, 4876-4882.

Van Trappen, S., Mergaert, J. \& Swings, J. (2004). Loktanella salsilacus gen. nov., sp. nov., Loktanella fryxellensis sp. nov. and Loktanella vestfoldensis sp. nov., new members of the Rhodobacter group, isolated from microbial mats in Antarctic lakes. Int J Syst Evol Microbiol 54, 1263-1269. 